\title{
A Cretaceous calamity? \\ The Hypsilophodon Bed of the Isle of Wight, southern England
}

\author{
Robert A. Coram ${ }^{1}$, Jonathan D. Radley² \& David M. Martill ${ }^{3}$ \\ ${ }^{1} 6$ Battlemead, Swanage, Dorset BH19 1PH, UK rob@britishfossils.co.uk \\ ${ }^{2}$ School of Geography, Earth and Environmental Sciences, University of Birmingham, Edgbaston, \\ Birmingham B15 2TT, UK \\ ${ }^{3}$ School of Earth and Environmental Sciences, University of Portsmouth, Portsmouth P01 3QL, UK
}

Complete or near-complete skeletons of the herbivorous dinosaur Hypsilophodon foxii occur frequently in a metre-thick band of mudstone in the Lower Cretaceous Wessex Formation of the Isle of Wight. The reasons for this accumulation have been the subject of some debate and this article examines new sedimentological clues that provide a plausible explanation for these dinosaurs' demise.

The Lower Cretaceous Wealden Supergroup (Barremian- early Aptian; approximately 130 to 122 million years old) of the Isle of Wight, comprises the Wessex and Vectis formations, both of which are well exposed in the cliffs of Brighstone Bay on the south-west coast of the island (Fig. 1). The older Wessex Formation, predominantly red mudstones and sandstones, was deposited in and around a meandering river. The climate was warm to very hot and of Mediterranean aspect; hot, dry spells punctuated by heavy rainfall that transformed the ancient Wessex river floodplains seasonally into swampy wetlands.

The Wessex Formation has long been known as a source of non-marine fossils, including plants, molluscs, insects, fish, reptiles such as crocodiles, pterosaurs and turtles, and very rare (and very 
small) mammals. What it is most famous for, however, is the bones and occasionally skeletons of dinosaurs. Studies of the dinosaur fossils by the palaeontological pioneers of Buckland, Mantell, Owen and Huxley in the nineteenth century were important for shaping our understanding of these iconic animals.

Most of the dinosaur remains are found in what are commonly referred to as 'plant debris beds': grey-green silty mudstones, that contrast markedly with the predominantly red and variegated mudstones and sandstones making up most of the formation. The PDBs (as they have become known) may reach 1.5 metres thick, although they are usually considerably thinner $(1-30 \mathrm{~cm})$ and are generally of limited lateral extent (tens of metres). Most conspicuously, they are packed with pieces of black lignitised wood, commonly pyritised and sometimes burnt, and pebbles of calcrete. This, along with the less frequent bone material, is interpreted as terrestrial debris transported to ephemeral ponds, abandoned channels and other depressions on the river floodplains by storm-induced floods. The dinosaur remains are almost always incomplete, often merely isolated bones, the dead bodies clearly having remained unburied for long periods and the bones often scavenged, scattered, trampled and sometimes waterworn. Diversity of dinosaur remains in the plant debris beds is high, and includes ornithopods, thyreophorans, sauropods and theropods.

There is, however, a well-known exception to this more typical mode of preservation. A band of reddish-green silty mudstone up to about a metre thick at the very top of the Wessex Formation in Brighstone Bay is famous for its well-preserved remains of the small (generally under two metres long), bipedal, herbivorous dinosaur Hypsilophodon foxii. This skeleton-rich layer has accordingly been named the Hypsilophodon Bed (Figs 2, 3, 4).

\section{Mass mortality?}

What is of particular interest regarding the dinosaurs in the Hypsilophodon Bed is that all, or nearly all, were fossilised as whole skeletons (although usually some or most of each skeleton is destroyed by coastal erosion of the soft Cretaceous strata before it is spotted and collected). Some of the remains 
have evidently been disturbed and disarticulated by water movements or soil-forming processes in the enclosing clay and the burrowing activities of an organism - probably a crustacean - which might even have scavenged the carcasses, since the preserved burrows (known as Beaconites; Fig. 4) are sometimes intimately associated with the bones. Other skeletons are less disturbed, lying as if sleeping, with every bone, even within the delicate skull, in the position it would have occupied in life. In some specimens long bony tendons remain suspended in position around the tail vertebrae, indicating that the bodies were still fully-fleshed at burial (Fig. 5). None of the skeletons show any signs of pre-burial scavenging by crocodiles or predatory dinosaurs, which are well-known in the Wessex Formation. It is apparent that these Hypsilophodon were buried very rapidly shortly after death, or perhaps burial was the cause of their death?

Furthermore, there evidently was a large number of them. Based on specimens in museums and private collections (over twenty just in London's Natural History Museum, for example), in the region of a hundred separate individuals have been collected from the Hypsilophodon Bed since the first example was described by Thomas Henry Huxley roughly 150 years ago. No doubt many more skeletons have been lost to marine erosion.

The Hypsilophodon Bed is exposed along a kilometre of cliff-face, appearing in the cliff-top at Barnes High (National Grid Reference SZ 437 808) where it dips gently towards the shore, , finally disappearing beneath the beach shingle near Cowleaze Chine (National Grid Reference SZ 444 801). It yields Hypsilophodon along its entire length, but logically this cannot be its maximum productive extent. How far it extends inland and under the shore and how far out it once extended into what is now open sea is similarly not known, but it is a reasonable assumption that entombed in this bed are, or were, many hundreds, if not thousands of intact skeletons.

Of course, all these dinosaurs, albeit swiftly buried, may not necessarily have died at once, and the Hypsilophodon Bed could simply have recorded a number of separate calamities or the steady accumulation of the remains of hapless individuals that died over a great many years, and were perhaps also transported by rivers from a much larger catchment area. These scenarios are unlikely, 
however. If the Hypsilophodon deaths were significantly spread out over time and/or space, one would expect to see their bodies accompanied by remains of other dinosaurs. But, unlike the plant debris beds, the Hypsilophodon Bed accumulation is monospecific. Apart from very rare fish and even rarer isolated bones of other reptiles, Hypsilophodon is all that occurs in an articulated condition. There is also no transported plant material such as wood. Additionally, one would not expect the skeletons to be so consistently well-preserved, but to reflect more the inevitable vagaries of different times, and perhaps different causes of death.

Alternatively, could all the Hypsilophodon have been killed and buried over the course of a single unusual event? Again, probably not. A close examination of the Hypsilophodon Bed shows that it actually comprises two separate mudstone layers (referred to here as the lower and upper Hypsilophodon beds; Fig. 2), both of which yield skeletons. The lower is mostly deep-red, the upper green-mottled pinkish-red, and along much of the section the two beds are separated by generally thin sandstone (more of which below) indicating a break, or at least a change, in sedimentation (Figs 2, 6). The upper bed, which is the thicker of the two (up to about $60 \mathrm{~cm}$ ), has historically produced the most skeletons. It seems, therefore, that there were a minimum of two separate mortality events. Since each layer is relatively thin and individual Hypsilophodon skeletons can occupy much of the thickness of a layer, two events may well be the maximum.

Mass mortality is further supported by the wide range of sizes exhibited by the dinosaurs (with total lengths ranging between less than one metre to over two metres). Hypsilophodon was evidently, at least at times, a gregarious animal, perhaps forming herds made up of tens, and perhaps hundreds of individuals, both juvenile and adult. Similarly large aggregations of terrestrial animals are far from unknown today. Flamingos flock in their thousands around African lagoons and African wildebeest form vast migratory herds, which in turn attract sizeable congregations of crocodiles at river crossings.

What could have caused the mass death and burial of these Hypsilophodons approximately 125 million years ago? It has been suggested that the preserved Hypsilophodon represent members of a 
herd or herds that perished in quicksand. However, the remains of dinosaurs inferred to have died as a result of miring (like the Triassic prosauropod Plateosaurus in Germany) typically show preferential preservation of the mired legs or hindquarters; the exposed remainder of the skeletons having been disturbed or destroyed by scavengers, decay and weathering on the surface of the quicksand. The Hypsilophodon skeletons do not demonstrate this type of preservation pattern, nor do their hind limbs tend to occur in a vertical or subvertical orientation in the sediment, indicative of miring. Mired dinosaurs, too, might be expected to be more clustered around the margins of quicksand bodies, not spread over at least a kilometre of terrain.

The wide extent of the Hypsilophodon Bed and its enclosed skeletons suggests an alternative explanation. Mature rivers such as those of the Wealden typically meander across broad flat floodplains. There are consequently two main kinds of deposit found in this type of environment: those laid down in the river channel itself, and floodplain sediments, formed from mud and silt washed over the top of the channel during floods. Channel sediments, including those in the Wealden, tend to be laterally restricted by the base and sides of the original river channel. Although the plant debris beds can similarly be of restricted distribution, having been laid down in surface ponds or hollows, Wealden flood plain deposits are often of wider extent with essentially level bases, reflecting the unconfined spread of the sediment across the surrounding land surface. The Hypsilophodon Bed is of wide extent with a more-or-less flat base, indicating that it formed on the floodplain rather than in a channel.

For a river to deposit sediment on the floodplain, the water carrying the sediment has to overtop the river bank. This occurs on a very large scale today in places with big rivers like China and the USA, and the effect can be devastating to human property and life. The main immediate cause of death for humans and livestock is drowning. The lower and upper layers of the Hypsilophodon Bed could, therefore, correspond to massive overbank floods which carried sufficient water and sediment to drown and instantaneously entomb herds of Hypsilophodon. Are there any further sedimentological clues to support this? 


\section{The smoking gun?}

The banks of rivers like the Mississippi, which flooded New Orleans following Hurricane Katrina in 2005, are often naturally raised above the surrounding low-lying floodplain- these banks are known as levees. Sometimes levees are naturally breached during high water flow, leading to a catastrophic outpouring of sediment-laden river water through the break. As the speed of the flow decreases beyond the ruptured levee, the sediment is dumped on the floodplain: coarser sand nearer the break and finer and more easily transported silt and mud further away, forming a sheet-like body of floodplain sediment known as a crevasse splay.

This distinctive pattern can be observed in ancient deposits, including the Hypsilophodon Bed. At either end of its one-kilometre exposure on the Isle of Wight, the Hypsilophodon Bed is consistently made up of its lower and upper mudstone units. However, approximately halfway between these points, almost the entire thickness of both beds (approximately one metre) becomes replaced by sandstone, the lower part of which appears to fill a broad and shallow confined channel, the upper part evidently over-spilling and thinning rapidly in both directions along the cliff-face before finally disappearing (Figs 4, 6). This sandstone body bears the hallmarks of a crevasse splay, and a closer look at it and the associated Hypsilophodon Bed mudstones suggests a possible sequence of events (numbers below refer to those shown on Fig. 6).

1. First to take place was a destructive flood, or series of floods, which deposited the mudstone of the lower Hypsilophodon Bed, killing and entombing Hypsilophodon which had 'flocked' on the lowlying floodplain, perhaps to exploit a rich but ephemeral food source such as plant debris stranded by retreating floodwaters, or the shoots of riparian plants colonising freshly deposited alluvium. Mudcracks and rootlet traces within the mudstone indicate that there was then a lull, during which the surface of the bed was exposed and supported some plant growth.

2. This quiet phase was not to last, however. A major river channel, some way distant, burst its banks again and water loaded with sand, silt and mud spread rapidly across the floodplain, carving smaller channels and gullies. One such channel cut through the lower Hypsilophodon Bed and is 
preserved today as the lower part of the sandstone body seen in the cliff section (Fig. 6). Successive pulses of sediment-laden floodwater deposited several sandstone layers containing transported red mudstone pebbles, and penetrated by numerous Beaconites burrows (Fig. 4). Thin mudstone seams between the sandstone layers indicate periods of waning water flow.

3. Eventually the small channel was filled to the level of the surrounding landscape, which is now the top of the lower Hypsilophodon Bed. The next great pulse of floodwater through the more distant levee breach could now flow unconfined across the floodplain, forming the sheet-like crevasse splay which makes up the higher part of the Hypsilophodon Bed sandstone. Consequently, this sandstone has an essentially flat base. Distinctive sedimentary structures known as climbing ripples are prevalent throughout (Fig. 4). These attest to rapid sedimentation and are characteristic of certain Recent crevasse splays of similar thickness deposited over timescales measurable in hours (for example, on the Yellow River delta in China). These, and the absence of noticeable sedimentary breaks in the upper, sheet-like part of the sandstone, strongly suggest that it was deposited by a single flood surge. The sandstone is convex-topped, and from its thickest point it thins rapidly in both directions along the cliff-face, eventually becoming a poorly cemented and discontinuous sandstone band sandwiched between the lower and upper Hypsilophodon beds (Fig. 2) before disappearing entirely, its total lateral extent being in the order of $600 \mathrm{~m}$. Beyond, the sandstone blends vertically and laterally into soft siltstone and then typical upper Hypsilophodon Bed mudstone; strongly suggesting that these different sediment types are the product of diminishing water flow from a single flooding event.

The crevasse splay sandstone could, therefore, be the 'smoking gun' regarding the formation of the upper Hypsilophodon Bed and the demise of the dinosaurs now entombed within it. This scenario is rendered more plausible because Hypsilophodon remains have been recovered from both the sandstone and the 'normal' mudstone lithofacies which replaces it, laterally and vertically. It is, nevertheless, probable that the single preserved crevasse splay was not responsible for all the sediment that buried this Hypsilophodon herd, since recent crevasse splays of similar size do not carry 
with them the quantities of mud required to form the full known extent of the upper Hypsilophodon Bed. What is perhaps more likely is that simultaneous levee breaches along other points of the main river contributed multiple pulses of mud and silt over a wide area of the floodplain.

Following this major flood, as was the case with the lower Hypsilophodon Bed, there was a period of comparative calm and subaerial exposure, during which there was, again, surface plant growth, testified by preserved rootlets, as well as the formation of soil structures such as calcretes and rhizoliths.

4. Then, quite suddenly, there was a profound and effectively permanent change in the regional environment. About twenty million years before the destruction of the Hypsilophodon herds, the sea that had covered this part of southern Britain for most of the Jurassic Period withdrew, and hundreds of metres of non-marine sediments were laid down: first the lagoonal and lacustrine Purbeck beds (not exposed on the Isle of Wight), then the alluvial Wessex Formation of the Wealden, as sand and mud entered the basin from uplands to the west. Immediately above the Hypsilophodon Bed, however, this sequence was reversed. The predominantly red mudstones of the Wessex Formation abruptly give way to laminated grey mudstones and distinctive light-coloured sandstone (known as the 'White Rock') of the overlying lagoonal Vectis Formation. This is our first 'sniff' of the Cretaceous sea, as mildly brackish water spread inland, hinting at an open marine environment beyond.

Although well-preserved Hypsilophodon remains have occasionally been found much lower down in the Wessex Formation on the Isle of Wight, it is tempting to speculate why they occur in by far the greatest density in the topmost metre. It might be significant that the Vectis lagoon was inexorably encroaching, perhaps forcing beleagured local Hypsilophodon populations to congregate in increasingly large groups and take greater risks as their lowland habitat steadily reduced in size and the windows of opportunity for grazing became shorter. For a time, dinosaurs, including large ornithopods, continued to trample the lagoon shorelines, leaving their characteristic footprints in the White Rock sandstone at the base of the Vectis Formation (Fig. 7), and locally crushing the 
Hypsilophodon skeletons in their shallow grave below (Fig. 8). Eventually, however, as the lagoon waters continued to spread, Hypsilophodon's floodplain habitat was extinguished forever. Soon coastal storms would breach offshore barriers and usher in the fully marine conditions that would last for over fifty million years, right up to the end of the Cretaceous Period and the end of the age of the dinosaurs.

\section{Acknowledgements}

Thanks are expressed to Steve Hutt and Mick Green for useful discussion and other assistance. The BBC is also acknowledged for facilitating excavation of the Hypsilophodon Bed during the June 2001 'Live from Dinosaur Island' broadcasts, to which the authors contributed. This article is dedicated to the memory of Roland Goldring, who supported the authors in diverse ways on numerous occasions.

\section{Suggestions for further reading}

Galton, P.M. 1974. The ornithischian dinosaur Hypsilophodon from the Wealden of the Isle of Wight. Bulletin of the British Museum (Natural History), Geology, v.25, pp.1-152.

Huxley, T.H. 1870. On Hypsilophodon foxii, a new dinosaurian from the Wealden of the Isle of Wight. Quarterly Journal of the Geological Society, London, v.26, pp.3-12.

Martill, D.M. \& Naish, D. (eds) 2001. Dinosaurs of the Isle of Wight. Field Guide to Fossils: Number 10. The Palaeontological Association, London. 433 pp.

Radley, J.D. \& Allen, P. 2012. The Wealden (non-marine Lower Cretaceous) of the Wessex Subbasin, southern England. Proceedings of the Geologists' Association, v.123, pp.319-373.

Sander, P.M. 1992. The Norian Plateosaurus bonebeds of central Europe and their taphonomy. Palaeogeography, Palaeoclimatology, Palaeoecology, v.93, pp.255-299. 
Sweetman, S.C. \& Insole, A.N. 2010. The plant debris beds of the Early Cretaceous (Barremian) Wessex Formation of the Isle of Wight, southern England: their genesis and palaeontological significance. Palaeogeography, Palaeoclimatology, Palaeoecology, v.292, pp.409-424. 


\section{Figures}

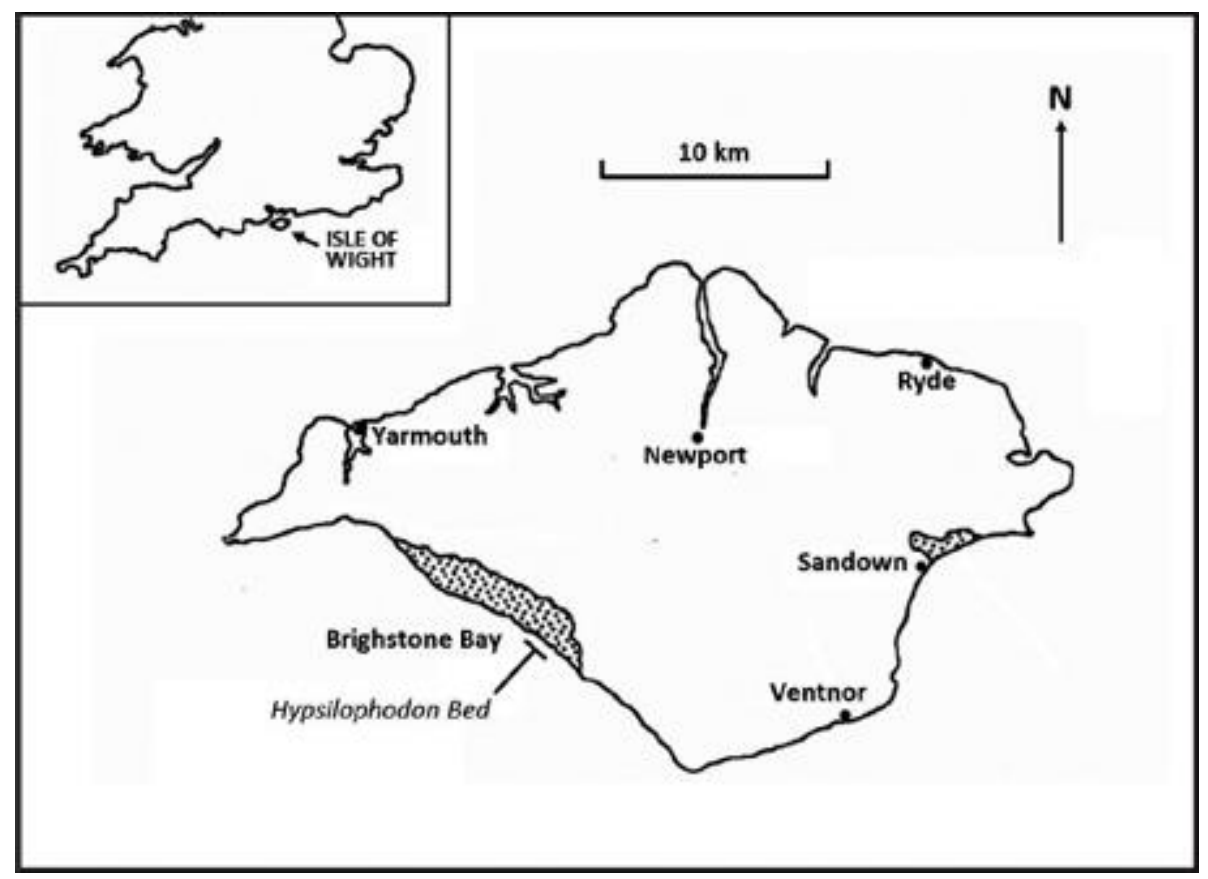

Fig. 1. Hypsilophodon Bed, Isle of Wight; Location map. Wealden Supergroup outcrop stippled.

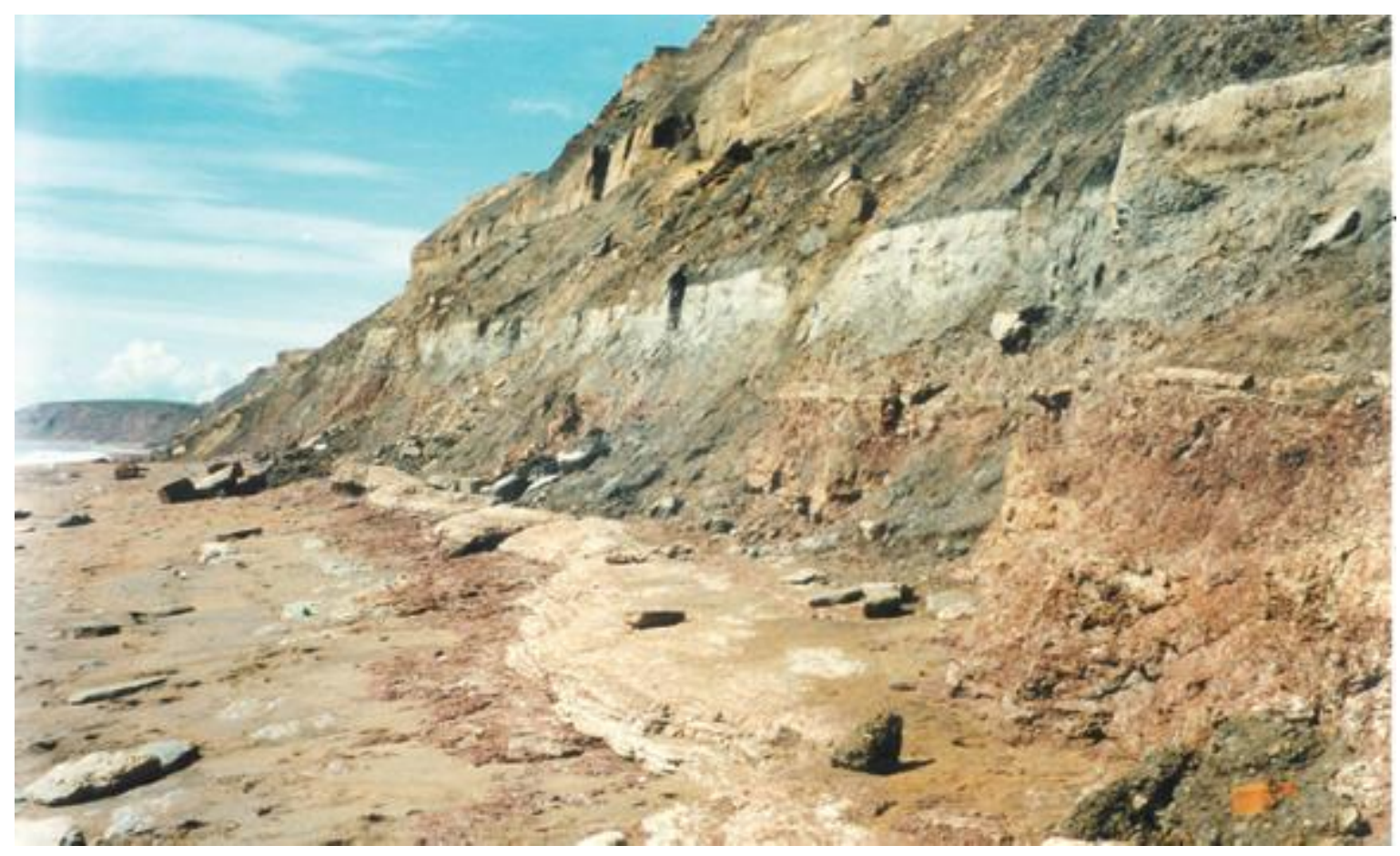

Fig. 2. The Hypsilophodon Bed as exposed 200 m north-west of Cowleaze Chine, Isle of Wight.

Note thin sandstone layer separating upper and lower parts of the bed. 


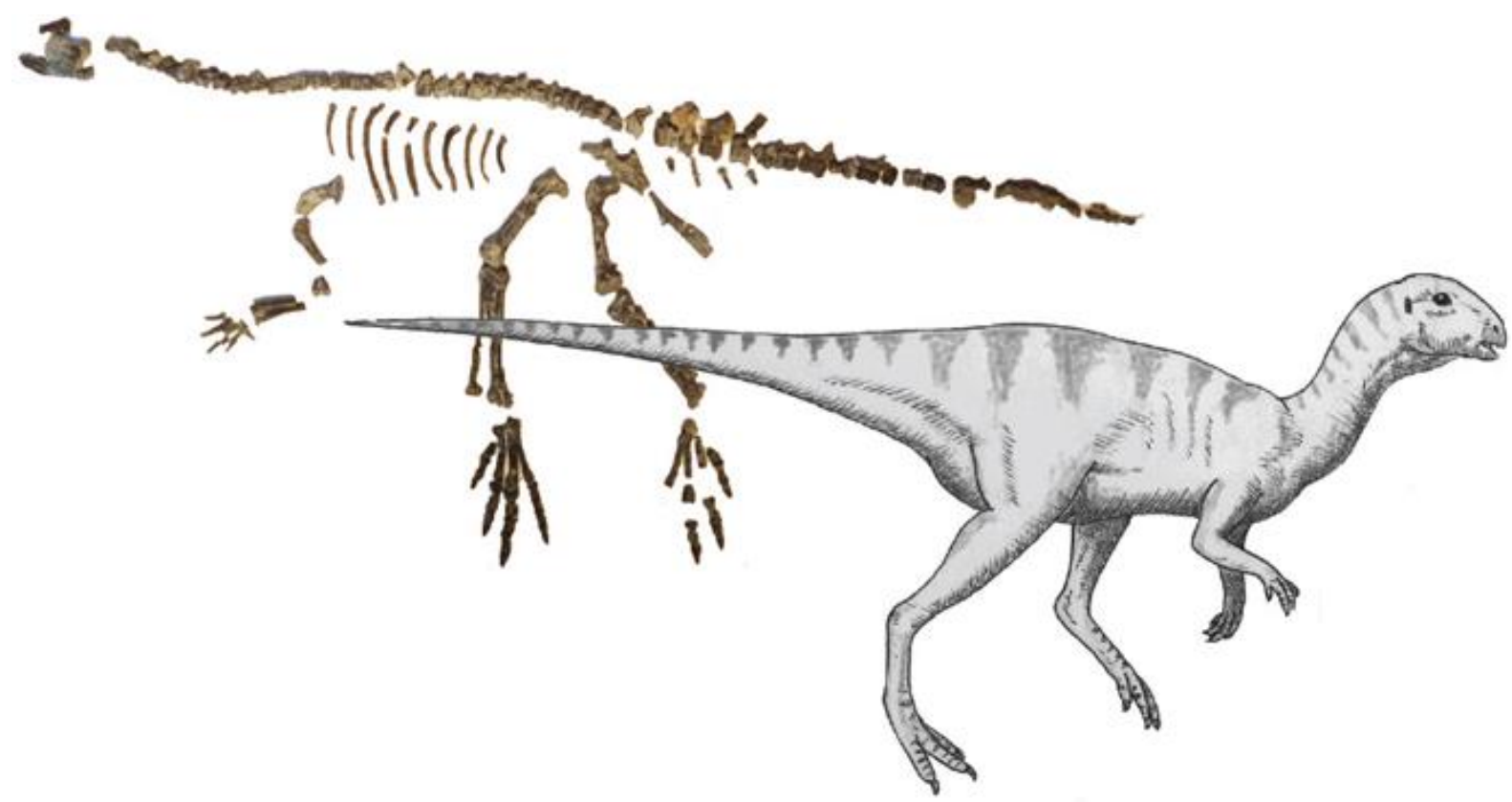

Fig. 3. A fairly complete $1.5 \mathrm{~m}$ long Hypsilophodon skeleton collected in 1996 with a life restoration.

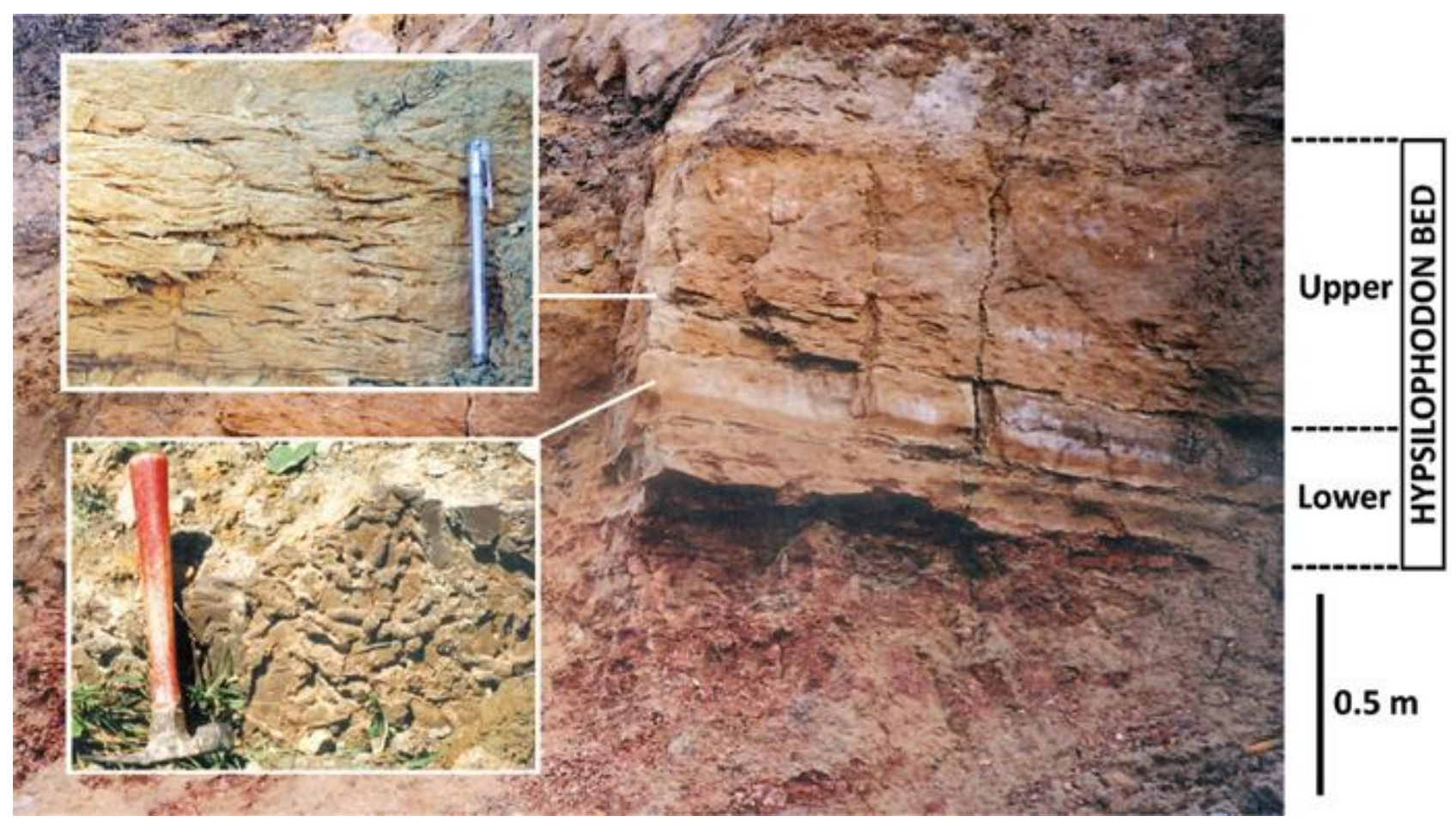

Fig. 4. Sandstone lithofacies of Hypsilophodon Bed, approximately $450 \mathrm{~m}$ north-west of Cowleaze Chine. Inset top: detail of climbing ripples. Inset bottom: Beaconites burrows on underside of a fallen block. 


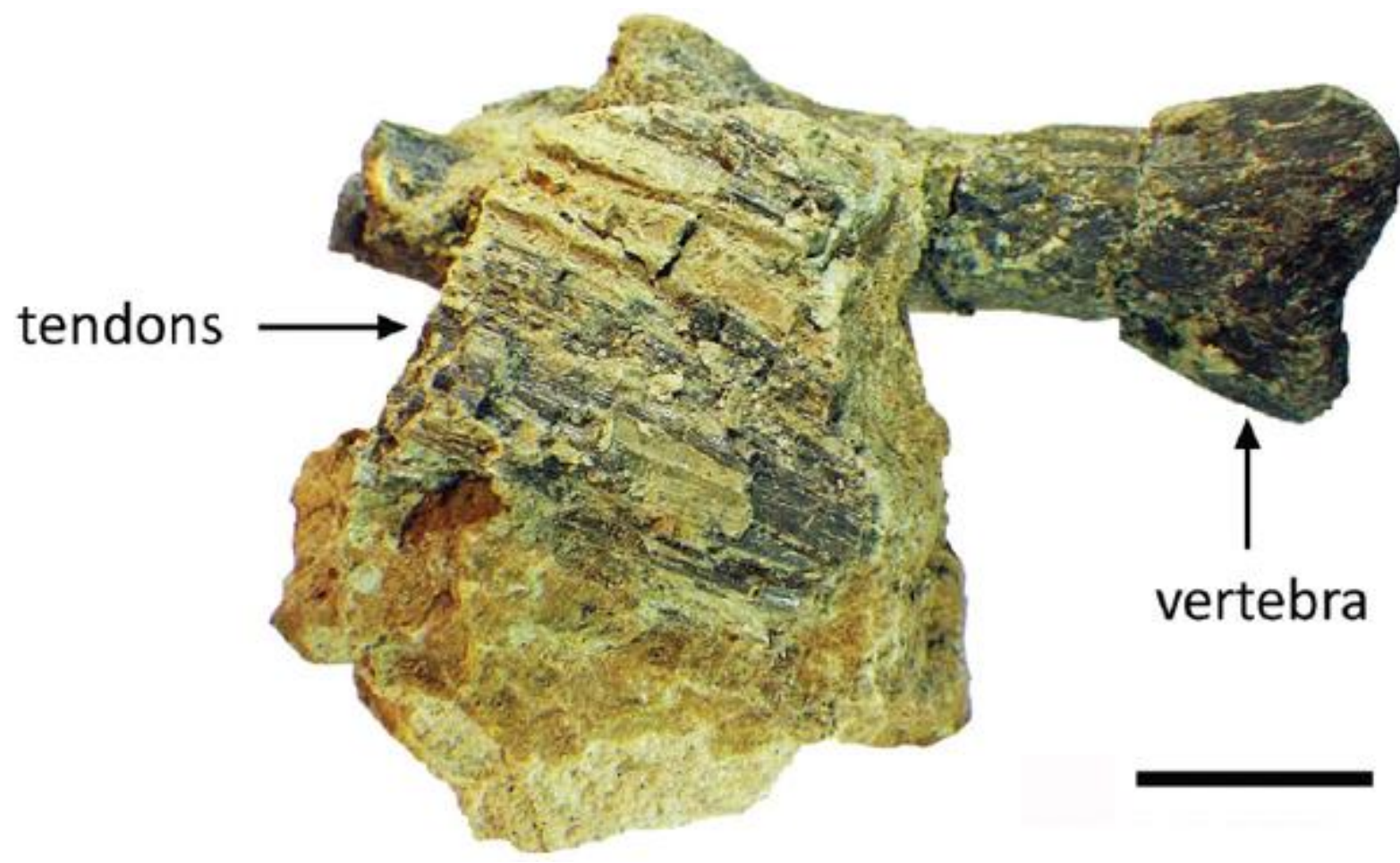

Fig. 5. Hypsilophodon tail vertebra with tendons preserved in presumed life position. Scale bar 1 $\mathrm{cm}$.

BARNES HIGH

$100 \mathrm{~m}$

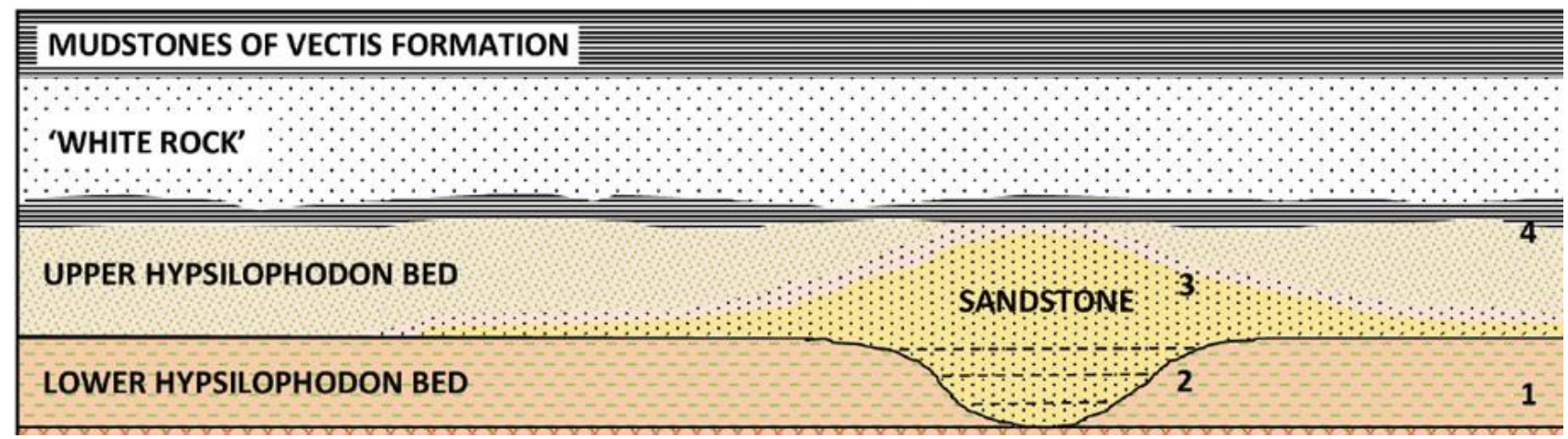

Fig. 6. Highly simplified stratigraphic section of the Hypsilophodon Bed exposure, showing occurrence of presumed crevasse splay sandstone. Numbers refer to numbered comments in text. Note that the vertical scale is greatly exaggerated, meaning that the sandstone development has a much more sheet-like geometry in the actual section. 


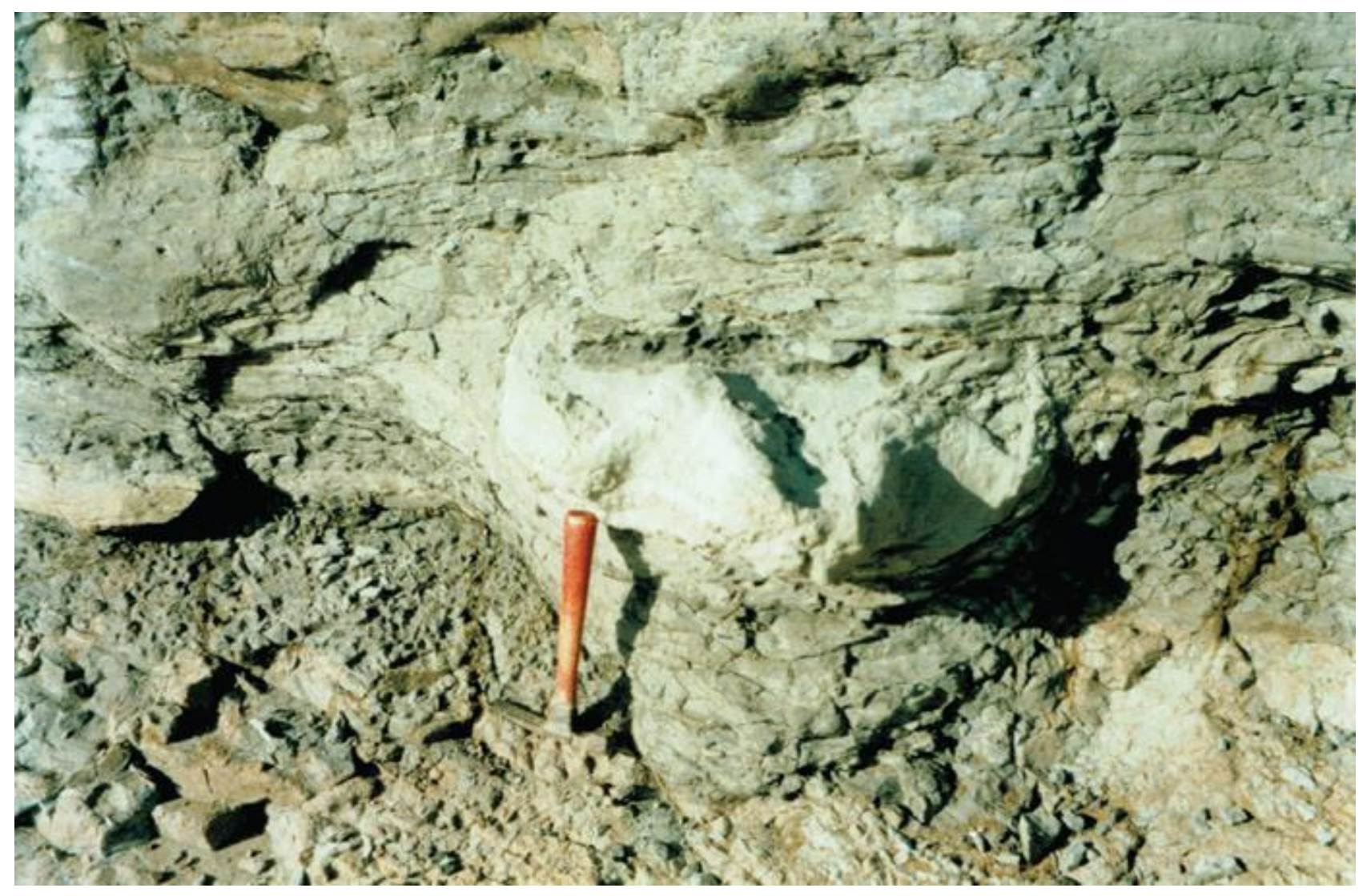

Fig. 7. Iguanodontid footprint in 'the White Rock' at the base of the Vectis Formation. Hammer length $28 \mathrm{~cm}$ (head resting on top of upper Hypsilophodon Bed). 


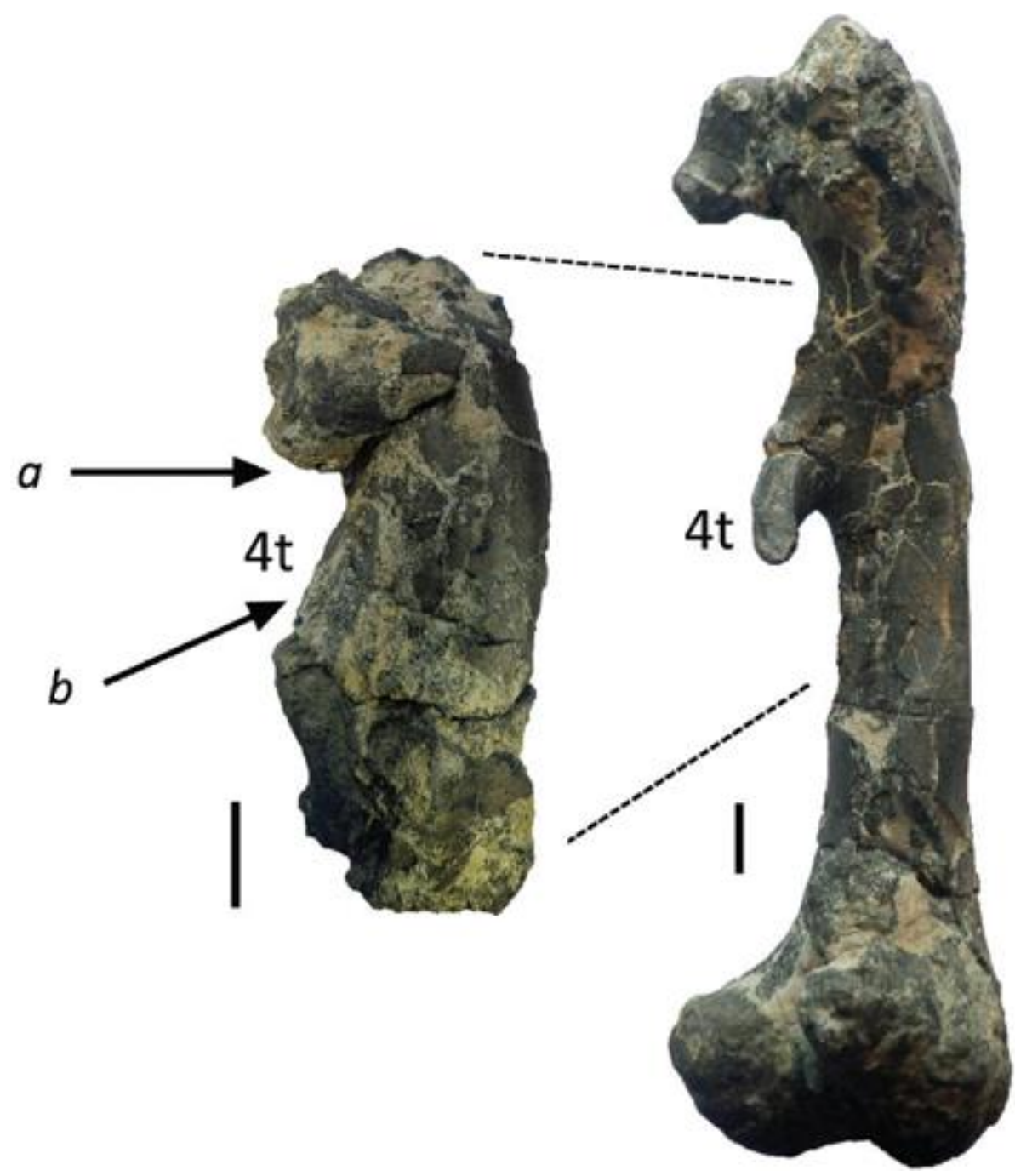

Fig. 8. Partial Hypsilophodon femur (left) with presumed trampling damage. There is a rightangled fracture at $a$ and the fourth trochanter (4t) at $b$ was broken off prior to fossilisation (the lower part of the bone was removed by recent erosion). Complete femur shown on right for comparison. Scale bars $1 \mathrm{~cm}$. 